\title{
Discussion: the futures of global history
}

\author{
Richard Drayton ${ }^{1}$ and David Motadel ${ }^{2}$ \\ ${ }^{1}$ Department of History, King's College London, The Strand, London WC2R 2LS, UK \\ E-mail: richard.drayton@kcl.ac.uk \\ ${ }^{2}$ Department of International History, London School of Economics and Political Science (LSE), \\ Houghton Street, London WC2A 2AE, UK \\ E-mail: d.motadel@Ise.ac.uk
}

\begin{abstract}
Global history has come under attack. It is charged with neglecting national history and the 'small spaces' of the past, with being an elite globalist project made irrelevant by the anti-globalist politics of our age, with focusing exclusively on mobile people and things, and with becoming dangerously hegemonic. This article demonstrates that global history is intertwined with the histories of the nation and the local, individuals, outsiders, and subalterns, and small and isolated places. Moreover, global history has directly addressed immobility and resistances to flow, and remains relatively weak in the discipline, versus the persistent dominance everywhere of national history. The article offers a new short history of the rise of the contemporary idiom of global history, and a prospect for a future in which scholars may find, through collaboration, alternatives to the European weights and measures of the past, and to the dominance of Anglophone historians. It argues that we should no more reverse the 'global turn' than we should return history's gaze only to propertied white men. Rather than a retreat from global history, we need it more than ever to fight against myths of imperial and national pasts, which often underpin nationalist populisms.
\end{abstract}

Keywords global history, historiography, imperial history, transnational history, world history

'If you believe you are a citizen of the world, you are citizen of nowhere', declared Theresa May in the autumn of 2016 to the Conservative Party conference, questioning the patriotism of those who still dared to question Brexit. Within a month, 'Make America great again' triumphed in the polls in the United States. From Erdogan's Turkey, to Putin's Russia, to Modi's India, a current of anti-globalization nationalisms is in full flow.

The storm clouds are indeed dark. They seem even to cast their shadows on the world of historical scholarship, provoking the Princeton Latin American historian Jeremy Adelman to offer a lament about the academic field of global history. ${ }^{1}$ For Adelman, it seems, the relevance of the field was derived from 'globalization' and its recent Whiggish boosters, ergo: 'In our fevered present of Nation-X First, of resurgent ethno-nationalism, what's the point of

1 Jeremy Adelman, 'What is global history now?', Aeon, 2 March 2017. 
recovering global pasts?' Contained in his rebuke of global history, and of its rootless cosmopolitan practitioners, is the idea that it sought to 'eclipse' national frames of enquiry. It was not the first time that such a jeremiad about global history had issued from the sages of Princeton's Dickinson Hall. In late 2013, David Bell, the distinguished historian of France, had shrugged in a notorious New Republic book review, that 'perhaps the "global turn", for all of its insights and instruction, has hit a point of diminishing returns'. 'Perhaps it is time', he mused, 'to turn back' to the 'small spaces'.

Adelman and Bell do put their fingers on many serious problems, and their swashbuckling essays provide a helpful basis for a reflection on the state of global history. But the claim that 'resurgent ethno-nationalism' in some way challenges the premises of global history is odd. For, global historians have long noted that forms of ethno-national resistance to globalization were themselves responses to new kinds of global connections. All the fundamentalist upheavals and jihads of the last hundred years, to give one obvious example, arose in response to increasing connection. ${ }^{3}$ In any event, modern nationalisms, across the nineteenth and twentieth centuries, both inside and outside Europe, were incubated within transnational and trans-imperial connections. ${ }^{4}$ It is not even a new story. The mercantilisms of early modern European states, and the subsequent fabrications of Louis XIV and Whig England, for example, responded to the new acceleration of European and global trade propelled by the silver of Potosí and the gold of the Caribbean and Africa. ${ }^{5}$ Anti-globalization is itself a phenomenon of globalization, and usually seeks to reconstitute the nation's place in the world rather than to retreat into a disconnected autarky. Trump's 'America first' and its international analogues are only the most recent incarnations of this reactionary dialectics.

Even stranger is the idea, not confined to Adelman and Bell, that global history implies a rejection of the smaller scales of historical experience, in particular the nation. It is not merely

2 David Bell, 'This is what happens when historians overuse the idea of the network', New Republic, 26 October 2013.

3 Nikki R. Keddie, 'The revolt of Islam, 1700 to 1993: comparative considerations and relations to imperialism', Comparative Studies in Society and History, 36, 3, 1994, pp. 463-87; and, more detailed, the contributions in David Motadel, ed., Islam and the European empires, Oxford: Oxford University Press, 2014. For a brilliant more general account of this dialectic, see Cemil Aydin, The politics of anti-Westernism in Asia: visions of world order in pan-Islamic and pan-Asian thought, New York: Columbia University Press, 2007.

4 Rebecca Karl, Staging the world: Chinese nationalism at the turn of the twentieth century, Durham, NC: Duke University Press, 2002; James Belich, Replenishing the earth: the settler revolution and the rise of the Angloworld, 1783-1939, Oxford: Oxford University Press, 2009; and Sebastian Conrad, Globalisation and the nation in imperial Germany, Cambridge: Cambridge University Press, 2010, provide fascinating case studies of the emergence of national consciousness (and nationalism) as the result of global connections. Similarly, scholars have emphasized the importance of transnational and trans-imperial connections in the history of anti-imperial nationalism, see, for example, Jonathan Schneer, 'Anti-imperial London: the pan-African conference of 1900', in Felix Driver, ed., Imperial cities: landscape, display and identity, Manchester: Manchester University Press, 1999, pp. 254-67; Benedict Anderson, Under three flags: anarchism and the anti-colonial imagination, London: Verso, 2005; Erez Manela, The Wilsonian moment: self-determination and the international origins of anticolonial nationalism, Oxford: Oxford University Press, 2007; Sugata Bose, A hundred horizons: the Indian ocean in the age of global empire, Cambridge: Cambridge University Press, 2009; Leslie James, George Padmore and decolonization from below, New York: Palgrave Macmillan, 2015; and Michael Goebel, Anti-colonial metropolis: interwar Paris and the seeds of Third World nationalism, Cambridge: Cambridge University Press, 2015. Matthias Middell and Katja Naumann, 'Global history and the spatial turn: from the impact of area studies to the study of critical junctures of globalization', Journal of Global History, 5, 1, 2010, pp. 149-70, discuss the phenomenon in more general terms.

5 Richard Drayton, 'Of empire and political economy', in Sophus Reinert and Pernille Røge, eds., The political economy of empire in the early modern world, New York: Palgrave Macmillan, 2008, pp. vii-xi; Pierre Vilar, A history of gold and money, 1450-1920, New York: Verso, 1991; and Marjorie Grice-Hutchinson, Early economic thought in Spain, 1177-1740, London: Allen and Unwin, 1978. 
that global historians are often keenly anchored in national history, or that much innovative recent work has operated at the level of micro-history, following the experience of the global in particular small places or through clusters of individuals. More crucially, national history has, from its origins, been in dialogue with however people have understood the cosmopolitan. We might usefully rediscover how history at the scales of the local, 'national', regional, and global has been entangled with the very origins of human study of the past. Such an enquiry might help us to better understand, beyond the vanities of polemic, where we are now and what might be the futures of global history.

\section{The pasts of global (and national) history}

Global history is an approach to the past which has two key modes. On the one hand, the comparative approach seeks to understand events in one place through examining their similarities with and differences from how things happened somewhere else. ${ }^{6}$ This is opposed to, or combined with, the connective approach, which elucidates how history is made through the interactions of geographically (or temporally) separate historical communities. ${ }^{7}$ Both of these are very old, although the connected and egalitarian terms on which the world's histories met by the late twentieth century gave them radically new meanings.

Sima Qian, born in the second century BCE, is considered the first and greatest of the classical Chinese historians. The 130 chapters of his Grand scribe's records combine lapidary Tacitean studies of personalities - not just rulers or generals, as was conventional, but artisans, assassins, artists, even among them women - with studies of war, economy, and society. ${ }^{8}$ While China was his focus, Sima set his history into the context of the non-Chinese world, drawing on ethnographic observations made by travellers and officials at all of the Han Dynasty's frontiers. He distinguished the Chinese through a discipline of comparison with foreigners, who, he insisted, were as human and full of potential as his own people.

6 Patrick O’Brien, 'Historiographical traditions and modern imperatives for the restoration of global history', Journal of Global History, 1, 1, 2006, pp. 3-39, provides a discussion of the problem of global history that leans heavily towards the comparative. For perhaps the most ambitious major recent work in comparative history, see Victor Lieberman, Strange parallels, vol. 1 (Integration on the mainland: Southeast Asia in global context, c.800-1830) and vol. 2 (Mainland mirrors: Europe, Japan, China, South Asia, and the Islands: Southeast Asia in global context, c.800-1830), Cambridge: Cambridge University Press, 2003 and 2010. For one transit from comparative to global history, see Valéria Guimarães, 'Da história comparada à história global: imprensa transnacional e o exemplo do le Messager de São Paulo (From comparative history to global history: the transnational press and the example of the São Paolo Messager)', Revista Instituto Histórico e Geográfico Brasileiro, 466, 2015, pp. 87-120.

7 Sanjay Subrahmanyam, 'Connected histories: notes towards a reconfiguration of early modern Eurasia', Modern Asian Studies, 31, 3, 1997, pp. 735-62; Serge Gruzinski, 'Les mondes mêlés de la monarchie catholique et autres connected histories', Annales: Histoire, Sciences Sociales, 56, 1, 2001, pp. 85-117; Caroline Douki and Philippe Minard, 'Histoire globale, histoires connectées: un changement d'échelle historiographique?', Revue d'histoire moderne et contemporaine, 54-4bis, 5, 2007, pp. 7-21; Michael Werner and Bénédicte Zimmermann, 'Vergleich, Transfer, Verflechtung: der Ansatz der Histoire croisée und die Herausforderung des Transnationalen', Geschichte und Gesellschaft, 28, 4, 2002, pp. 607-36; and Michael Werner and Bénédicte Zimmermann, 'Beyond comparison: histoire croisée and the challenge of reflexivity', History and Theory, 45, 1, 2006, pp. 30-50. Or see, as an example, one classic connective work of global history written from the perspective of Latin America: Jeremy Adelman, Sovereignty and revolution in the Iberian Atlantic, Princeton, NJ: Princeton University Press, 2006.

8 William J. Nienhauser, ed., The Grand scribe's records, 9 vols. (to date), Bloomington, IN: Indiana University Press, 1994-. On Sima Qian, see Siep Stuurman, 'Herodotus and Sima Qian: history and the anthropological turn in ancient Greece and Han China', Journal of World History, 19, 1, 2008, pp. 1-40; and Craig Benjamin, " "But from this time forth history becomes a connected whole": state expansion and the origins of universal history', Journal of Global History, 9, 3, 2014, pp. 357-78. 
Indeed, global history, at its foundations, is not a new genre. Universal history, by which we mean a history that seeks to tell a history of all of humankind, its origins, and perhaps its destiny, is in fact one of the most ancient kinds of history, always in connection with how each culture understood its peculiar history. The historians of ancient Greece, from Herodotus onwards, framed their accounts of Attic prowess relative to universal history. The ethno-national community was understood relative to the xenoi, the stranger friends at one's immediate frontiers, and the barbaroi, those understood as radically different. In the hands of Polybius and Eusebius, a tradition of juxtaposing the inner history of Romans and Christians to those who lay beyond set the frame for what became the discipline of history a millennium later in modern Europe. But it was not confined to that western peninsula of Asia: to the east, in the medieval Arab world, alMas'udi, al-Tabari, and Ibn Khaldun wrote histories of the world, and in fourteenth-century Persia, Rashid al-Din brought together learned men from across Eurasia, including those born in China and Europe, to write a world history from the perspective of the Mongols. ${ }^{9}$

National history, in its nineteenth-century European incarnations, was similarly intertwined with a kind of global history. If Ranke is the symbol of nation-centred history, it must always be remembered that he and his disciples around Europe, such as Acton in England and Monod in France, understood the careful study of the archival trace at the level of the nation to be only a preliminary to some future enterprise of universal history. This was the high play that Ranke indulged in his essay on 'Die großen Mächte'. ${ }^{10}$ His Geschichten der romanischen und germanischen Völker sought to examine the historical event both in its local particularity (that 'eigentlich' which is generally oversimplified as 'actually') and in its general universal character. ${ }^{11}$ Its first chapter explained that at the core of the common history of Europe were three 'external enterprises': great migrations, the Crusades, and the colonization of foreign countries.

The Rankeans' view of universal history had the shared history of Christendom at its heart, from which modern world civilization was assumed to diffuse. Such a perspective was in quiet collusion with a post-1815 world order for which Europe appeared to be the military, technical, and economic vanguard. Its impact, which endured into the late twentieth century, was to constitute extra-European history either as the imperial history of European nations or as exotic theatres, of marginal relevance to the main forces and events in universal history. Challenges to diffusionist universal history, such as Eric Williams's Capitalism and slavery (1944), were greeted with hostility or studiously ignored. ${ }^{12}$ Hugh Trevor-Roper's infamous description of African history in 1965 as 'the meaningless gyrations of barbarous tribes

9 El-Mas'udi's historical encyclopedia, entitled 'Meadows of gold and mines of gems', 8 vols., London: Oriental Translation Fund of Great Britain and Ireland, 1841; The history of al-Tabari: an annotated translation, 40 vols., New York: State University of New York Press, 1985-98; Ibn Khaldūn, The Muqaddimah: an introduction to history, trans. Frank Rosenthal, Princeton, NJ: Princeton University Press, 1958; and W. M. Thackston (trans. and ed.), Rashiduddin Fazlullah's Jami'u't tawarikh: compendium of chronicles, 3 vols., Cambridge, MA: Harvard University Department of Near Eastern Languages and Civilizations, 1998-99.

10 Leopold Ranke, 'Die großen Mächte', Historisch-Politische Zeitschrift, 2, 1833, pp. 1-51.

11 Ranke's 'eigentlich' is not merely a positivistic claim; it is an Aristotelian assertion of how that which was actual was the concrete expression of the universal or general, see Leopold Ranke, Geschichten der romanischen und germanischen Völker von 1494 bis 1535, Leipzig and Berlin: Reimer, 1824. The essays in Wolfgang J. Mommsen, ed., Leopold von Ranke und die moderne Geschichtswissenschaft, Stuttgart: KlettCotta, 1988, provide some further insights.

12 Eric Williams, Capitalism and slavery, Chapel Hill, NC: University of North Carolina Press, 1944. For a discussion of Williams and other Caribbean and Latin American nineteenth- and early twentieth-century precursors to global history, see Rafael Marquese and João Paulo Pimenta, 'Tradições de história global na América Latina e no Caribe (Global history traditions in Latin America and the Caribbean)', História da Historiografia, 17, 2015, pp. 30-49. 
in picturesque but irrelevant corners of the globe' was perhaps the swansong of that way of seeing, which subordinated universal history to the Whiggish self-constructions of each European nation and a collective Eurocentrism. ${ }^{13}$

Global history, as we know it, came out of two post-1950 revolutionary changes. The first, obvious, and often invoked, was the collapse of the European empires and the demand from and for post-colonial nations for their 'own' histories and for a share in the story of the cosmopolitan. Decolonization challenged the white supremacist assumptions which had quietly ordered two centuries of the human sciences in the West. Euro-American universities responded to this after about 1960 by sprouting 'area studies' enclaves, although new strength in Asia, Africa, and the Middle East was often at the margins of history departments, in which national and European history remained dominant. As the West's universities gradually opened themselves to people of colour and scholars from the non-West, however, these margins grew in their strength and centrality.

The second, intertwined, revolution, rarely recognized, was the impact of 'history from below'. Historical practice after 1960 no longer found its inevitable centre in understanding the voices of those privileged white men preserved in the West's state archives. Once we began to pay attention to historical agents below the level of the state, we looked outwards: E. P. Thompson's classic 1967 essay on time and work discipline in Britain, for example, repeatedly reaches towards transnational comparison. ${ }^{14}$ People now sought to understand historical processes from the view of, and through the agency of, subordinate groups. There is a direct epistemological connection between the inclusion of women, the poor, and non-whites as historical agents, and a new late twentieth-century attention to historical agents in and from the 'Global South'. New attention went towards understanding 'Western' science and philosophy as shaped by imperial expansion and extra-European agency. ${ }^{15}$ To this extent, there is no way back from the 'global turn' in our century, any more than we could go back to a history which paid no attention to women or the poor.

The World History Association emerged in the United States in 1982. It reflected how, in schools and universities in that country, uninterrogated 'Western civilization' courses were giving way to new attention to extra-European history and international interactions. Underpinning the initiative was a new body of bold transnational histories which rethought universal history under the impress of 'area studies' history, in particular the work of William McNeill, Marshall Hodgson, Philip Curtin, and Sidney Mintz. ${ }^{16}$ In 1990, the World History Association founded the Journal of World History, now in its twenty-eighth volume, which Jerry Bentley, its founding editor, declared would foster 'historical

13 Hugh Trevor-Roper, 'The rise of Christian Europe', The Listener, 70, 1963, p. 871.

14 E. P. Thompson, 'Time, work-discipline, and industrial capitalism', Past \& Present, 38, 1, 1967, pp. 56-97.

15 Richard Drayton, Nature's government: science, imperial Britain and the 'improvement' of the world, New Haven, CT: Yale University Press, 2000; and Susan Buck Morss, 'Hegel and Haiti', Critical Inquiry, 26, 4, 2000, pp. 821-65.

16 William P. McNeill, The rise of the West: a history of the human community, Chicago, IL: Chicago University Press, 1963; William P. McNeill, Plagues and peoples, New York: Garden Press, 1976; Marshall Hodgson's extraordinary 1960s essays, collected posthumously as Marshall G. S. Hodgson, Rethinking world history: essays on Europe, Islam, and world history, ed. Edmund G. Burke III, Cambridge: Cambridge University Press, 1993; Marshall G. S. Hodgson, The venture of Islam: conscience and history in a world civilization, 3 vols., Chicago, IL: Chicago University Press, 1974; Philip Curtin, Cross-cultural trade in world history, Cambridge: Cambridge University Press, 1984; and Sidney Mintz, Sweetness and power: the place of sugar in modern history, London: Allen Lane, 1985. 
analysis undertaken not from the viewpoint of national states, but rather from that of the global community'. ${ }^{17}$ Patrick O'Brien, then Director of the Institute of Historical Research in London, began in 1996 to organize a seminar series on 'Global history over the very long term', which was quickly partnered by a 'World history seminar' organized by John Darwin, Peter Carey, and one of the authors of this article, Richard Drayton, in Oxford. Yet it is fair to say that the vast majority of historians paid very little attention to these initiatives, particularly in Britain.

'Global history' acquired a new momentum, visibility, and sense of collective purpose, however, with the cresting of both the realities and idea of 'globalization' around 2000. A Cambridge workshop on the 'History of globalization' in summer 2000, which resulted in A. G. Hopkins' edited volume Globalization in world history, was both a symbol of and a stimulus to this new tide. ${ }^{18}$ Two books in particular marked the new moment: Kenneth Pomeranz's The great divergence (2000), perhaps the single most influential twentyfirst-century work of history to date, and Christopher Bayly's The birth of the modern world - the latter appearing in 2004, the bicentenary of the Haitian Revolution, with the startling image of the Black Jacobin Citoyen Belley on its cover. ${ }^{19}$ Excited by the rise of Asia in the 1990s, global economic historians began a vast project to assess why in the mid eighteenth century it was Europe, and not China or India, that took the leap to industrialization and 'modernity'. ${ }^{20}$ Pulled by historians of slavery, American historians became increasingly receptive to the project of Atlantic history. ${ }^{21}$ Indian Ocean history and other 'thallasologies' emerged quickly in the wake of the Atlanticists. ${ }^{22}$ Migration and diasporas became central objects of research in relation to these oceanic histories. ${ }^{23}$

17 Jerry H. Bentley, 'A new forum for global history', Journal of World History, 1990, 1, 1, pp. iii-v.

18 A. G. Hopkins, ed., Globalization in world history, London: Pimlico, 2002; see also A. G. Hopkins, 'The historiography of globalization and the globalization of regionalism', Journal of the Economic and Social History of the Orient, 53, 1/2, 2010, pp. 19-36; and A. G. Hopkins, American empire: a global history, Princeton, NJ: Princeton University Press, 2018.

19 Kenneth Pomeranz, The great divergence, Princeton, NJ: Princeton University Press, 2000; and Christopher Bayly, The birth of the modern world, London: Wiley-Blackwell, 2004. Strikingly, the image of Citoyen Belley also appeared on the cover of Jürgen Osterhammel, Sklaverei und die Zivilisation des Westens, Munich: Carl Friedrich von Siemens Stiftung, 2000, which was published around the same time.

20 Pomeranz was only the best-known historian on this terrain. See also Bin Wong, China transformed: historical change and the limits of European experience, Ithaca, NY: Cornell University Press, 2000; Joseph Inikori, Africans and the industrial revolution in England: a study in international trade and economic development, Cambridge: Cambridge University Press, 2002; and Prasannan Parthasarathi, Why Europe became rich and Asia did not: global economic divergence, 1600-1850, Cambridge: Cambridge University Press, 2011.

21 Marcus Rediker and Peter Linebaugh, The many-headed hydra: sailors, slaves, commoners, and the hidden history of the revolutionary Atlantic, London: Verso, 2000; and Bernard Bailyn, Atlantic history: concept and contours, Cambridge, MA: Harvard University Press, 2005.

22 Kären Wigen, 'Introduction: Oceans of History forum', American Historical Review, 111, 3, 2006, pp. 717-21; Markus P. M. Vink, 'Indian Ocean studies and the "new thalassology"', Journal of Global History, 2, 1, 2007, pp. 41-62; Isabel Hofmeyr, 'The Black Atlantic meets the Indian Ocean: forging new paradigms of transnationalism for the Global South: literary and cultural perspectives', Social Dynamics, 33, 2, 2007, pp. 3-32; Matt K. Matsuda, Pacific worlds: a history of seas, peoples, and cultures, Cambridge: Cambridge University Press, 2012; Donna R. Gabaccia and Dirk Hoerder, eds., Connecting seas and connected ocean rims: Indian, Atlantic, and Pacific Oceans and China Seas migrations from the 1830s to the 1930s, Leiden: Brill, 2011.

23 See, inter alia, Robin Cohen, Global diasporas: an introduction, London: University College London Press, 1997; the essays in Ulrike Freitag and W. G. Clarence-Smith, eds., Hadrami statesmen, scholars and statesmen in the Indian Ocean, 1750s to 1960s, Leiden: Brill, 1997; John Thornton, Africa and the Africans in the making of the Atlantic world, 1400-1800, Cambridge: Cambridge University Press, 1998; Adam McKeown, Melancholy order: Asian migration and the globalization of borders, New York: Columbia University Press, 2008; and Andrew Arsan, Interlopers of empire: the Lebanese diaspora in colonial French West Africa, London: Hurst, 2014. 
In 2003, a large grant launched the Global Economic History Network, connecting forty-nine historians in universities across the world. Out of this enterprise came the Journal of Global History, which located itself explicitly in the terrain of the history of globalization, asserting through this a 'subtle difference between the closely related endeavours of global and world history'. ${ }^{24}$ No consensus emerged, then or since, however, about the utility of this distinction between 'world' and 'global' history, and in practice these flags sheltered very similar initiatives. A decolonized British imperial history chose to go global under the flag of 'world history', perhaps because it better represented the federal nature of its alliance with 'area studies' history. ${ }^{25}$ In 2006 in Cambridge, for example, the 'Extra-European History Group' of the Faculty of History became the 'World History Group', with its seminar renamed from the Commonwealth and Overseas History Seminar to the World History Seminar. ${ }^{26}$ From 2009, in London, similarly, the then eighty-year old Imperial History seminar, became the 'Imperial and World History seminar'. Elsewhere, at least for the post-1750 period, the banner of 'transnational history' has effectively taken some or all of the terrain of global history.

The appointment of historians from post-colonial countries, in particular India, to prestigious departments in the West, brought the views from the periphery into the centre. 'Area studies' historians began to write, or more accurately to be read, as global historians. European historians began (slowly) to take down the firewall between national and colonial history. British historians in the United States were in the lead here, in a cunning tactic to justify saving posts in their field. French historians soon followed, rediscovering C. L. R. James's longignored arguments about the interdependence of the French and Haitian revolutions, and other connections. ${ }^{27}$ At the same time, dramatic falls in travel costs made it possible for students to undertake international multi-archival doctoral research projects. Both the theory and the practice of global history became newly attractive. ${ }^{28}$

\section{The challenges of global history}

The wave of global history has, however, met with some resistance. Adelman and Bell in a way speak for many - and some of their criticisms are wholly fair. There is, for example, clearly an inflationary use of words such as 'global', 'transnational', and 'intercultural'. These are now brands under which, as Matt Connelly noted, historians often retail 'very conventional kinds

24 William Gervase Clarence-Smith, Kenneth Pomeranz, and Peer Vries, 'Editorial', Journal of Global History 1, 1, 2006, pp. 1-2.

25 For the global turn in British imperial history, see John Darwin, The empire project: the rise and fall of the British world-system, Cambridge: Cambridge University Press, 2009; and John Darwin, 'Empire and globe', in Maxine Berg, ed., Writing the history of the global: challenges for the 21st century, Oxford: Oxford University Press, 2013, pp. 197-9. For a discussion of the politics of the relationship between imperial and global history, see Richard Drayton, 'Where does the world historian write from? Objectivity, moral conscience and the past and present of imperialism', Journal of Contemporary History, 46, 3, 2011, pp. 671-85.

26 In 2003, Richard Drayton had already changed the faculty web page to describe 'Extra-European history' as 'a Cambridge name for two things: the histories of Asia, Africa, Latin America and the Pacific, on the one hand, and comparative approaches to world history, which often intrude into the histories of Europe and the United States, on the other'.

27 C. L. R. James, The Black Jacobins: Toussaint L'Ouverture and the San Domingo revolution, London: Secker and Warburg, 1938.

28 Merry E. Wiesner-Hanks, ed., The Cambridge world history, 7 vols. in 9 books, Cambridge: Cambridge University Press, 2015; and Akira Iriye and Jürgen Osterhammel, eds., A history of the world, 6 vols. (to date), Cambridge, MA: Harvard University Press, 2012-, for guides to the state of play in this rapidly changing field. 
of scholarship'. ${ }^{29}$ The field remains driven covertly by Western priorities, with the divergence debate and the global history of the French Revolution, to take two prominent examples, returning us often by non-Western routes to the idols of the old 'Rise of the West' historiography. It was within temporal boundary markers derived from European history that such masters of the genre as Bayly and Osterhammel ordered their global panoramas (although the latter chose to have no cut-off dates in the title of his book). Global history, in general, is dominated by Anglophone historians who seem unable or indisposed to read history written in other languages. ${ }^{30}$ How many historians outside rich universities in rich countries have access to the books, or can travel easily to the foreign archives and conferences that they would need to play the game of 'global history'? As Boubacar Barry, the doyen of history in Senegal, asked the opening plenary of the European Network in Universal and Global History conference in Paris in 2014, what exactly did 'global history' mean when Africans like himself found it almost impossible to obtain a Schengen visa? As Adelman bemoans, 'the high hopes for cosmopolitan narratives about "encounters" between Westerners and Resterners led to some pretty one-way exchanges about the shape of the global'. There are risks, inherent to global approaches, that, while similarities and convergences are identified, or sometimes forced, differences and interruptions are ignored. ${ }^{31}$

But many of Bell and Adelman's criticisms of this young field seem exaggerated and eccentric. It is true that there has been a dramatic number of new appointments in non-Western and global history, in particular in American and British universities, over the last decade. But Bell and Adelman's implication that the global has become hegemonic, displacing other fields, is rather off the mark. 'For many years now, it has been the rage among historians to uncover past global connections', David Bell writes. Hardly. Few historians commit themselves to the comparative and connective approaches, the signature methods of global history as a genre. In our seminar rooms and conference halls, national history is and remains the dominant form of historical inquiry. Across the world, the vast majority of university professorships and academic journals remain dedicated to national history. National histories - such as The English and their history (2015), the little island story of Brexit drummer Robert Tombs - are at the top of our bestseller lists. ${ }^{32}$ Pierre Nora's vituperative denunciation of the Histoire mondiale de la France (2017) was emblematic of a wider rejection by key French intellectuals of its attempt to understand French history as a dimension of global processes. ${ }^{33}$ Those appointed as South Asian, Chinese, and Middle Eastern historians usually work as faithfully

29 C. A. Bayly, Sven Beckert, Matthew Connelly, Isabel Hofmeyr, Wendy Kozol, and Patricia Seed, 'AHR conversation: on transnational history', American Historical Review, 111, 5, 2006, p. 1447.

30 It is particularly striking how Comparativ: Zeitschrift für Globalgeschichte und vergleichende Gesellschaftsforschung, founded in 1990 (making it almost as old as the Journal of World History) and which has engaged over 28 volumes with all the international developments in global history, is very rarely cited by Anglophone historians. Only two chapters of J. Belich, John Darwin, and Margret Frenz, eds., The prospect of global history, Oxford: Oxford University Press, 2016, appear to engage seriously with historical work not in English.

31 Studies which problematized the phenomenon are Frederick Cooper, 'What is the concept of globalization good for? An African historian's perspective', African Affairs, 100, 2001, pp. 189-213, for the case of African history; and Samuel Moyn, 'On the nonglobalization of ideas', in Samuel Moyn and Andrew Sartori, eds., Global intellectual history, New York: Columbia University Press, 2013, pp. 187-204, for the case of intellectual history.

32 Robert Tombs, The English and their history, London: Penguin, 2015.

33 Patrick Boucheron, ed., Histoire mondiale de la France, Paris: Seuil, 2017; for the review, see Pierre Nora, 'Histoire mondiale de la France', L'Obs, 2734, 30 March 2017, pp. 68-9. For a review in English, see Robert Darnton, 'A buffet of French history', New York Review of Books, 64, 8, 11 May 2017. 
within the national paradigm as most European historians, while not all 'area studies' historians welcome the transgressions of global history. National history remains the mode through which most contributions to 'world history' or 'international history' happen. It is rather premature of Bell to worry about 'diminishing returns'.

While global history is a charismatic field, it is small and weak. It will take more than two or three generations to overcome the profound Eurocentricity of our discipline in the West and we should not exaggerate how representative our history departments have become. Token Africanists and Middle Easternists are asked to represent the histories of entire regions over millennia. In Britain, as Adelman admits, Latin American history has fewer posts than it did in 1980. Huge areas of the human past remain in darkness. To take one startling case, there are about a dozen specialist historians of Indonesia - which has a population equivalent to Europe's - outside the Netherlands, Australia, and Indonesia.

It is true that connection remains prized by global historians. But is Adelman right that they are only concerned about 'integration and concord, rather than disintegration and discord'? On the contrary, considerable attention has gone to things which do not flow, and to resistances to the global which emerge within globalizations. Serge Gruzinski in $\mathrm{La}$ Pensée métisse (1999) and Les Quatres Parties du monde (2004) has described how what he calls 'European standardization', a kind of cultural resistance to the impact of the exotic, accompanied Habsburg expansion into the early modern world. ${ }^{34}$ Margot Finn has similarly written about 'frictions' as a dimension of the imperial experience, of resistance and opposition to flows and exchanges. ${ }^{35}$ Commodity historians have written about the 'anticommodity' as a phenomenon which arises in the midst of global exchange. ${ }^{36}$ Interruptions, reversals, and processes of de-globalization have long been of interest to global historians. Historians have demonstrated again and again that periods of global integration could end. Such major works as Bayly's Birth of the modern world, Jürgen Osterhammel's Verwandlung der Welt (2009; published in English as Transformation of the World, 2014) and indeed such precursors as Marshall Hodgson and Michael Mann - examined the fragility of global connections and the dynamics of disruption. ${ }^{37}$ There is a voluminous body of work on the breakdown of connections in the early modern Islamic imperial world. The 'divergence debate', from Pomeranz to Prasannan Parthasarathi's Why Europe grew rich and Asia did not (2011), has been about breakdowns of trade links, as much as connections. ${ }^{38}$ Harold James's perceptive Creation and destruction of value (2009) has shown that breakdowns of globalization have been as much part of the world's economic activity as integration. ${ }^{39}$ Vanessa Ogle's Global transformation of time (2015) is as much about the local and national fractures of globalization as about any seamless and

34 Serge Gruzinski, La Pensée métisse, Paris: Fayard, 1999; and Serge Gruzinski, Les Quatres Parties du monde: Histoire d'une mondialisation, Paris: La Martinière, 2004.

35 Margot Finn, 'Frictions of empire: colonial Bombay's probate and property networks in the 1780s', Annales: Histoire, Sciences Sociales, 65, 5, 2010, pp. 1175-1204.

36 The essays in Sandip Hazareesingh and Harro Maat, eds., Local subversions of colonial cultures: commodities and anti-commodities in global history, New York: Palgrave Macmillan, 2016, provide a good overview.

37 Bayly, Birth of the modern world; Jürgen Osterhammel, Die Verwandlung der Welt: eine Geschichte des 19. Jahrhunderts, Munich: C. H. Beck, 2009. For the earlier works, see Hodgson, Rethinking world history; and Michael Mann, The sources of social power, 4 vols., Cambridge: Cambridge University Press, 1986-2013.

38 Parthasarathi, Why Europe grew rich.

39 Harold James, The creation and destruction of value: the globalization cycle, Cambridge, MA: Harvard University Press, 2009. 
coherent convergence. ${ }^{40}$ Pierre Singaravélou's luminous Tianjin cosmopolis (2017) reveals the overlap of globalization and its crisis in a single frame. ${ }^{41}$ Studying interruptions and connections are not mutually exclusive.

Nor is it fair to condemn global history as focused on elite actors. Global history made visible the outsiders - slaves, the colonized, and other actors at the margins long ignored by the discipline in the West. James's Black Jacobins (1938), ignored by the generation of French historians who trained Bell, is only an early example. In his pioneering work of global labour history, Workers of the world, Marcel van der Linden looked at ordinary workers, farmers, and sharecroppers - not the winners of globalization. ${ }^{42}$ Others, like L.L. Robson, Roger Ekrich, and Clare Anderson, have traced the transportation of convicts to penal colonies. ${ }^{43}$ The wretched of Van Diemen's Land or Devil's Island were hardly a cosmopolitan elite. Historians such as Myron Echenberg, Timothy Parsons, Gregory Mann, David Killingray, and Tarak Barkawi have brought back the experiences of hundreds of thousands of colonial subalterns in the world wars. ${ }^{44} \mathrm{New}$ trans-imperial and transnational histories have illuminated the global life of religion in the flows of ordinary believers - missionaries, pious slaves, and hajj pilgrims. ${ }^{45}$ Global historians have always shown an interest in the losers of global integration, and in those who travelled in steerage rather than on the promenade deck. ${ }^{46}$

Moreover, global history has never just focused on globetrotters. Adelman's binary of 'globalists' versus 'the ones who cannot move' does not stand. Historians have repeatedly illuminated how global integration engaged people who otherwise appear isolated from the global. Take the movement of commodities - sugar, silver, diamonds, tea, porcelain, opium,

40 Vanessa Ogle, The global transformation of time: 1870-1950, Cambridge, MA: Harvard University Press, 2015. For the fractured time of globalization, its contradictory flows which integrate 'una pluralidad de temporalidades, con diferentes ritmos', see also Hugo Fazio, 'La historia global: ¿encrucijada de la contemporaneidad?', Revista de Estudios Sociales, 23, 2006, pp. 59-72.

41 Pierre Singaravélou, Tianjin cosmopolis: une autre histoire de la mondialisation, Paris: Seuil, 2017.

42 Marcel van der Linden, Workers of the world: essay toward a global labor history, Leiden: Brill, 2008; and, for an excellent case study, Minu Haschemi Yekani, Koloniale Arbeit: Rassismus, Migration und Herrschaft in Tansania (1885-1914), Cologne: Campus, 2018.

43 L. L. Robson, The convict settlers of Australia: an enquiry into the origin and character of the convicts transported to New South Wales and Van Diemen's Land 1787-1852, Melbourne: Melbourne University Press, 1976; A. Roger Ekrich, Bound for America: the transportation of British convicts to the colonies, 17181775, Oxford: Clarendon Press, 1990; Clare Anderson, Legible bodies: race, criminality and colonialism in South Asia, London: Bloomsbury, 2004; and Clare Anderson, Subaltern lives: biographies of colonialism in the Indian Ocean world, 1790-1920, Cambridge: Cambridge University Press, 2012.

44 Myron J. Echenberg, Colonial conscripts: the Tirailleurs Sénégalais in French West Africa 1857-1960, London: James Currey, 1991; Timothy H. Parsons, The African rank-and-file: social implications of colonial military service in the King's African Rifles, 1902-1964, London: James Currey, 1999; Gregory Mann, Nativesons: West African veterans and France in the twentieth century, Durham, NC: Duke University Press, 2006; David Killingray, Fighting for Britain: African soldiers in the Second World War, Woodbridge: Boydell and Brewer, 2012; and Tarak Barkawi, Soldiers of empire: Indian and British armies in World War II, Cambridge: Cambridge University Press, 2017.

45 Barbara Watson Andaya, 'Between empires and emporia: the economics of Christianization in early modern Southeast Asia', Journal of the Economic and Social History of the Orient, 52, 4-5, 2009, pp. 963-97; William Gervase Clarence-Smith, Islam and the abolition of slavery, Oxford: Oxford University Press, 2006; John P. Slight, The British empire and the hajj, 1865-1956, Cambridge, MA: Harvard University Press, 2015; and the contributions in Umar Ryad, ed., The hajj and Europe in the age of empire, Leiden: Brill, 2016. The chapters in Abigail Green and Vincent Viaene, eds., Religious internationals in the modern world: globalization and faith communities since 1750, New York, 2012, provide further insights into the globalized worlds of faith communities in modern history.

46 McKeown, Melancholy order; and Sunil Amrith, Crossing the Bay of Bengal: the furies of nature and the fortunes of migrants, Cambridge, MA: Harvard University Press, 2013. 
and so on - which changed the lives of people no matter how mobile they were. ${ }^{47}$ As Fernand Braudel reminded us in the very first number of Annales, the impact of Caribbean gold crossing to Spain, for example, affected even the trans-Saharan caravan trade in the interior of Africa. ${ }^{48}$ Later, simultaneously with the rise of the trading cities of western Europe and the slave plantations of the Atlantic, came the Second Serfdom: east of a line which stretched from Hamburg to Venice, peasants were re-subordinated to a fierce discipline which ensured that wheat flowed to Danzig, Riga, Stettin, and Wismar, and that the products of the East and West Indies flowed to their masters. ${ }^{49}$ Tracing the flows of tobacco and chocolate in the Atlantic world, Marcy Norton's Sacred gifts, profane pleasures (2008) has vividly demonstrated how seamen and colonists from the Americas brought these products to Europe, from where they spread to the Middle East, Asia, and Africa. ${ }^{50}$ As tobacco and chocolate became more readily available, consumers in the most remote corners of the globe developed a taste for them. They might not have gone into the world, but the world came to them. Similarly, scholars of France have shown that global trade affected economy and society even of apparently 'isolated' places in eighteenth-century France's interior. ${ }^{51}$ Even the most rooted actors could have a cup of coffee, smoke a cigar, or sell cotton shirts in the local shop. Even the most isolated hermit could not (and cannot) escape global influences. Much as David Armitage has argued for a 'cis-Atlantic history' - that is to say, a history of regions which were shaped by the distant effects of Atlantic interactions - so we must insist on a cis-global history, lived in territories far from the apparent hotspots of trans-global processes or circulation. ${ }^{52}$

Even less is global history guilty of Bell's charge of neglecting individuals. Indeed, there is now a growing field of global micro-history - centred on the individual and family - which has shed light on major historical phenomena and should not be easily dismissed. ${ }^{53}$

47 What we might call the Warwick school of global economic history has explored in particular how luxury goods opened and thickened Eurasian connections with consequences which reached deep into the commercial hinterlands, see Maxine Berg, 'Asian luxuries and the making of the European consumer revolution', in Maxine Berg and Elizabeth Eger, eds., Luxury in the eighteenth century: debates, desires and delectable goods, New York: Palgrave Macmillan, 2002, pp. 228-44; Giorgio Riello, Cotton: the fabric that made the modern world, Cambridge: Cambridge University Press, 2013; Maxine Berg, Felicia Gottmann, Hanna Hodacs, and Chris Nierstrasz, eds., Goods from the East, 1600-1800: trading Eurasia, New York: Palgrave Macmillan, 2015; and Peter McNeil and Giorgio Riello, Luxury: a rich history, Oxford: Oxford University Press, 2016.

48 Fernand Braudel, 'Monnaies et civilisations: de l'or du Soudan à l'argent d'Amérique', Annales: Économies, Sociétés, Civilisations, 1, 1, 1946, pp. 9-22. For a more recent and wider-ranging intervention, see Toby Green, 'Africa and the price revolution: currency imports and socio-economic change in West and WestCentral Africa during the seventeenth century', Journal of African History, 57, 1, 2016, pp. 1-24; and Toby Green, A fistful of shells: money, power and revolution in Africa during the Atlantic slave trade era, London: Allen Lane, forthcoming 2019.

49 Fernand Braudel, Civilisation matérielle, economie et capitalisme, vol. 2 (Les jeux de l'échange), Paris: Armand Colin, 1979, pp. 310-17; and Richard Drayton, 'The collaboration of labour', in Hopkins, Globalization in world history, p. 102. For an explanation of the vital connection between export of sugar and coffee to the Baltic hinterlands of the Hanse cities and the French colonial economy, see Richard Drayton, 'The globalisation of France: provincial cities and French expansion, 1500-1800', History of European Ideas, 34, 4, 2008, pp. 424-30.

50 Marcy Norton, Sacred gifts, profane pleasures: a history of tobacco and chocolate in the Atlantic world, Ithaca, NY: Cornell University Press, 2008.

51 Emma Rothschild, 'Isolation and economic life in eighteenth-century France', American Historical Review, 119, 4, 2014, pp. 1055-82.

52 David Armitage, 'Three concepts of Atlantic history', in David Armitage and M. Braddick, eds., The British Atlantic world, 1500-1800, New York: Palgrave Macmillan, 2002, pp. 11-27.

53 Francesca Trivellato, 'Microstoria, storia del mundo e storia globale', in Paola Lanaro, ed., Microstoria: a venticinque anni da l'eredità immateriale, Milan: Franco Angeli, 2011, pp. 119-32, for a discussion of the problematic. De Vito and Gerritsen have framed a manifesto for a 'micro-spatial' global history, see Christian G. De Vito and Anne Gerritsen, eds., Micro-spatial histories of global labour, New York: Palgrave Macmillan, 2017. 
Natalie Zemon-Davis (among others) has looked at the odyssey of the Berber geographer Leo Africanus. ${ }^{54}$ John-Paul Ghobrial has traced the seventeenth-century global adventures of the Ottoman priest Ilias of Babylon, from Europe to South America. ${ }^{55}$ While Linda Colley, as Bell notes, has pursued the global trajectory of Elizabeth Marsh, Emma Rothschild has used the global lives of the Scottish Johnstone family as a lens through which to see the inner life of Britain's global empire. ${ }^{56}$ Gagan Sood has employed a single cache of documents to illuminate how family, religion, and kinship ties ordered the economic and cultural life of Islamicate west Asia in the middle of the eighteenth century. ${ }^{57}$ Jean Hébrard and Rebecca Scott have followed the trajectory of Rosalie, a slave from Senegambia in the Age of Revolution. ${ }^{58}$ And one of the authors of this article, David Motadel, is tracing the story of two globetrotting Persian shahs, who roamed the aristocratic world of the fin de siècle, from the Ottoman borderlands to the shores of Scotland, to offer a reinterpretation of the relationships between the world's sovereigns in an age of European domination. ${ }^{59}$

It is true that many global historians - particularly those of the great syntheses - prioritize structures over individuals, but this bias is surely as characteristic of national history. Where they do - as in Robert Allen's and Sven Beckert's very different attempts to explain the early modern global context for nineteenth-century industrial production - they surely answer Bell's opposite assertion that global history neglects making broader arguments and overarching narratives. ${ }^{60}$ While some global historians are tempted by David Christian's 'Big History', the vast majority prefer not to surrender their methods to the uncertain guesses of the natural sciences, and continue to work on sources and problems which address much smaller spaces, recent times, and human agency and experience. ${ }^{61}$

Equally to be resisted is the idea that global history is, or needs to be, the luxury trade of an elite minority. There is certainly a kind of global history practised, as Adelman charged, by the 'upper echelons of a higher education committed to an idyll of global citizenship'. But the historical profession in general is dominated by the offspring of the Euro-American white upper middle class, and one is more likely to find exceptions to this in global history than in many other fields.

54 Natalie Zemon-Davis, Trickster travels: a sixteenth-century Muslim between worlds, London: Faber and Faber, 2006.

55 John-Paul Ghobrial, 'The secret life of Elias of Babylon and the uses of global microhistory', Past \& Present, 222, 1, 2014, pp. 51-93.

56 Linda Colley, The ordeal of Elizabeth Marsh: a woman in world history, New York: Pantheon, 2007; and Emma Rothschild, The inner life of empires: an eighteenth-century history, Princeton, NJ: Princeton University Press, 2011.

57 Gagan Sood, India and the Islamic heartlands: an eighteenth-century world of circulation and exchange, Cambridge: Cambridge University Press, 2016.

58 Rebecca Scott and Jean M. Hébrard, Freedom papers: an Atlantic odyssey in the age of emancipation, Cambridge, MA: Harvard University Press, 2011.

59 David Motadel, 'Qajar shahs in imperial Germany', Past \& Present, 213, 1, 2010, pp. 191-235, provides some first insights.

60 Robert C. Allen, The British industrial revolution in global perspective, Cambridge: Cambridge University Press, 2009; Sven Beckert, Empire of cotton: a global history, New York: Knopf, 2014. For a global microhistorical approach to economic history, see Christof Dejung, Die Fäden des globalen Marktes: eine Sozialund Kulturgeschichte des Welthandels am Beispiel der Handelsfirma Gebrüder Volkart 1851-1999, Cologne, 2013.

61 David Christian, Maps of time: an introduction to 'Big History', Berkeley, CA: University of California Press, 2004; and David Christian, 'The return of universal history', History and Theory, 49, 4, 2010, pp. 5-26. Similarly, for the bridging from prehistory and the neurosciences to an explanation of the origins of European modernity, see Daniel Lord Smail, On deep history and the brain, Berkeley, CA: University of California Press, 2008 . 
What should be less controversial, however, is Adelman's warning that 'It is hard not to conclude that global history is another Anglospheric invention to integrate the Other into a cosmopolitan narrative on our terms, in our tongues.' There are indeed real inequalities, as we noted earlier, in the global trade in historical ideas: few are those who read in other European languages, let alone write in them, while rarer still are any capacities to read sources in Arabic, Chinese, or Hindi. One might insist, though, that this is not a problem peculiar to global history. United States historians of France are increasingly notorious for citing very little historiography not published in English. In strong contrast, global history as in the hands of Dipesh Chakrabarty, Arif Dirlik, and others, has provided a vehicle through which historical perspectives shaped by Asian, African, and Caribbean intellectual and language environments have quietly penetrated the Western mainstream. ${ }^{62}$

\section{Towards a new global (and national) history}

Global history has never been a demand that historians only pay attention to 'big' transnational phenomena. Its more important meaning is a change in the explanans of history: a new sensitivity to the historical agents, forces, and factors at scales above and below those of the nation or region. As Christophe Charle concluded, in a brilliant essay of 2013:

The global and the national approaches are neither radically incompatible universes, nor Russian dolls which nest simply and harmoniously one within the other, because each contributes to destabilize the other by obliging it to reconsider the implicit presuppositions on which it rests, and thus [together they] relaunch perpetually the question of the articulation of the scales of historical experience and of the diversity of themes which need to be taken into consideration, from the most particular to the most general. ${ }^{63}$

For Ranke and his heirs, an uninterrogated global was central to making national history. So too, in our moment, from quite the opposite direction, a self-conscious global history neither neglects 'the small spaces' nor evades the specificity and strangeness of disconnected historical experience. It is instead an invitation to the historian to be self-conscious of the jeux d'échelles, of the interdependence of the scales of space - village, province, nation, region, and world and time - days, decades, centuries - through which we explore and explain the past. A whole new genre of national histories is emerging which deliberately and self-consciously engage with the global. ${ }^{64}$ No longer can we only find the motor for the Industrial Revolution in the history of Lancashire, nor the causes for the French Revolution in the politics of Paris versus Versailles. ${ }^{65}$ The impact of global history is already visible in the transnational historical practice of those who do not think of themselves as global historians: one thinks of the European history of

62 Dipesh Chakrabarty, Provincializing Europe: postcolonial thought and historical difference, Princeton, NJ: Princeton University Press, 2000.

63 Christophe Charle, 'Histoire globale, histoire nationale? Comment réconcilier recherche et pédagogie', Le Débat, 3, 175, 2013, pp. 60-8.

64 Boucheron, Histoire mondiale de la France; and Andrea Giardina, ed., Storia mondiale dell'Italia, Rome: Laterza, 2017.

65 Suzanne Desan, Lynn Hunt, and William Max Nelson, eds., The French revolution in global perspective, Ithaca, NY: Cornell University Press, 2013, provides insightful chapters on the global histories of the French revolution. 
Richard J. Evans and Christopher Clark, or of Adam Tooze's experiment with an entangled European and United States history. ${ }^{66}$ Pace David Bell, there is no way home to even a French national history which finds its first or final causes purely within the hexagon. This is not to say that the global frame of reference is always the most relevant one: events at smaller scales of experience often unfold, and must be understood through, their own local logic. To be a global historian is often to study very specific places, institutions, and people and not to pretend to any general or generalizable claim. ${ }^{67}$

The old universal historians - Chinese, Arab, or European - sought to tell the story of other human communities as the frame for the history of their own tribe. What distinguishes the enterprise of global historians in the twenty-first century is our attempt to map the human past from and for the view of humanity as a whole. This project is young and fragile. The critics of global history are not wholly wrong to imply that it is always at risk of become a new mask for imperial history, as, hijacked by global elites, it constructs new panoramas of centre and peripheries. There are good reasons, for example, why many African historians retain a measure of hostility to Atlantic history, seeing it as paying attention more to those Africans most entangled in offshore European and American history. ${ }^{68}$ More generally, Euro-American history, particularly its Anglophone variants, exerts a palpable drag on all attempts at extra-European history, whether in its national, comparative, or connective dimensions.

Again, there are good reasons for this. To an overwhelming extent, the weights and measures which we bring to Asian, African, and Latin American history find their standards in north-west European history. ${ }^{69}$ Our attempts at reciprocal comparison are distorted by how much more the practitioners of global history know about the West. ${ }^{70}$ The legacy of the ways in which the world was integrated after about 1600, by and in response to European imperial and cultural power, is a cognitive Eurocentrism embedded in our methods. To give two examples, consider how Marshall Hodgson's proposition of a Song dynasty 'industrial revolution' or Indian historiography's constitution of a 'medieval period' depend on an imported set of referents which inherently corrupt the enterprise of measurement, ultimately cashing all phenomena into European standards. Concepts of 'revolution', 'class', 'progress', even concepts of 'empire' are lenses which distort at the same time as they allow us to see. The challenge for twenty-first-century global historians is to find new kinds of standards, in the physical sciences sense of the word - that is to say, methods, value judgments, and, most importantly, concepts - in the historical experience and historical

66 Richard J. Evans, The pursuit of power: Europe, 1815-1914, London: Penguin, 2016; C. M. Clark, 'Power', in Ulinka Rublack, ed., A concise companion to history, Oxford: Oxford University Press, 2011, pp. 131-56; C. M. Clark, The sleepwalkers, London: Penguin, 2013; and Adam Tooze, The deluge: the Great War and the remaking of global order, 1916-1931, London: Penguin, 2014.

67 Angelika Epple, 'Lokalität und die Dimensionen des Globalen: eine Frage der Relationen', Historische Anthropologie, 21, 1, 2013, pp. 4-25, provides some thoughts on locality and globality, and the contributions in Birgit Schäbler, ed., Area studies und die Welt: Weltregionen und neue Globalgeschichte, Vienna: Mandelbaum, 2007, discuss the integration of area studies and global history.

68 Megan Vaughan, 'Africa and global history', in Berg, Writing the history of the global, p. 200.

69 Chakrabarty, Provincializing Europe. Jorge Cañizares-Esguerra has repeatedly insisted that the problem is not merely one of Eurocentrism but of a distorted North Atlantic Anglophone idea of global history, see, for example, Jorge Cañizares-Esguerra, 'On ignored global “scientific revolutions"', Journal of Early Modern History, 21, 2017, pp. 420-32; and Jorge Cañizares-Esguerra and Adrian Masters, The radical Spanish empire: petitions and the creation of the New World, Cambridge, MA: Harvard University Press, 2018.

70 For one ingenious attempt, see Gareth Austin, 'Reciprocal comparison and African history: tackling conceptual Eurocentrism in the study of Africa's economic past', African Studies, 50, 3, 2007, pp. 1-28. 
self-consciousness of the tricontinent. ${ }^{71}$ We may even find our way to means of telling stories about the past which do not assume that history is being made from or for a given geographical or conceptual centre.

Global history has many futures. It needs to (continue to) break out of the twentieth-century mode of collecting national histories, which has sometimes turned global history into an equivalent of the children's card game 'Snap!'. Global history is not a federation of national and area studies history, as important and sovereign as these levels of analysis are. It is the product of engagements with the problem of the global, based on inspired comparative and connective thinking and not just the accumulation of examples from different regions. Yet there are not only intellectual but also practical considerations which will help the field to develop further. What seems clear is that the enterprise of the global will depend on collaboration. The edited volume and the work of translation are the natural media of global history. But these volumes, like many conferences, will be dialogues of the deaf if we do not work actively against the idea that the business of history can or should be done in English, or that only that which is translated or translatable deserves our attention. If we are serious about global history, more training in languages, particularly non-Western ones, is an obvious priority. This must be matched by an acceleration of the digitization of sources. We should prioritize this means of repatriation, via the internet, of the archives of Latin American, African, and Asian history held by former colonial powers, to be complemented by the digitalization of archives outside Europe and Northern America. ${ }^{72}$

Global history is more important than ever before. Academically, it remains one of the most dynamic and exciting fields of historical studies. Politically, it is of pressing importance as well. Retreating from global history would seem to be the least obvious response to the resurgence of populist nationalism. One of the reasons for the rise of nationalist populism is the dominance of national narratives in the popular historical imagination. As they connect present resentment to false memories of lost national grandeur, these narratives are already unselfconscious arguments about global history. New kinds of entangled national and global history, particularly as they speak to the public, have important kinds of work to do. They may even provide us with a sense of a shared global humanity. Lynn Hunt's vision that a 'more globally oriented history' would 'encourage a sense of international citizenship, of belonging to the world and not just to one's own nationality' and ultimately 'produce tolerant and cosmopolitan global citizens' could not be more timely. ${ }^{73}$ What is clear is that our students and fellow citizens are profoundly conscious of the global character of many of our contemporary challenges - global warming, refugee crises, pandemics, war and terror, unemployment, and the deterritorialization of capital. Our most pressing problems today go beyond the nation-state (even resurgent chauvinist nationalism and anti-globalism themselves). The

71 For an important attempt to bring into conversation Asian, African, Latin American, and European global history initiatives, see Sven Beckert and Dominic Sachsenmaier, eds., Global history, globally: research and practice around the world, London: Bloomsbury, 2018.

72 The Global Labour History Network offers a model for such sharing of sources and research. For a discussion of a model of a collective global research project, see Elise van Nederveen Meerkerk, 'Covering the world: textile workers and globalization, 1650-2000: Experiences and results of a collective research project', in Marcel van der Linden, ed., Labour history beyond borders: concepts and explorations, Linz: ITH, 2010, pp. 111-38.

73 Lynn Hunt, Writing history in the global era, New York: W.W. Norton, 2014. 
spectre of global history will continue to haunt the corridors of the world's ivory towers, inspiring some, perhaps, to see new worlds of past and future.

Richard Drayton is Rhodes Professor of Imperial History at King's

College London and editor of the 'Cambridge imperial and post-colonial studies' book series.

David Motadel is Assistant Professor of International History at the London School of Economics and Political Science (LSE).

They are co-convenors of the Imperial and World History Seminar of the Institute of Historical Research, London.

\title{
Replies to Richard Drayton and David Motadel
}

\author{
David A. Bell ${ }^{1}$ and Jeremy Adelman ${ }^{2}$ \\ ${ }^{1}$ Department of History, Princeton University, 129 Dickinson Hall, Princeton, NJ 08544-1017, USA \\ E-mail: dabell@princeton.edu \\ ${ }^{2}$ Department of History, Princeton University, 129 Dickinson Hall, Princeton, NJ 08544-1017, USA \\ E-mail: adelman@princeton.edu
}

We are grateful for the opportunity presented by the editors of the Journal of Global History to engage our critics, Richard Drayton and David Motadel. They have responded to our essays. But as we wrote them for different purposes and made different arguments in different times, and since we affectionately disagree on some points (though the Drayton and Motadel critique has a tendency to lump us together on key points we sometimes dispute), we have decided to keep our voices separate.

\section{Words from David Bell}

I'm delighted that my 2013 essay has, along with Jeremy Adelman's essay for Aeon, provoked such a lively and interesting defence of global history from Richard Drayton and David 
Motadel. But I fear that they get a couple of points wrong, and do not really engage with my major argument (which I elaborated upon at greater length in an article for French Historical Studies published in $2014^{74}$ ).

Although I did indeed say that much global history tends to neglect individuals, I did not charge the field as a whole with doing so, and specifically mentioned the sort of micro-histories that Drayton and Motadel rightly praise, singling out my colleague Linda Colley's terrific book The ordeal of Elizabeth Marsh. Drayton and Motadel also, somewhat puzzlingly, criticize me for saying that global history is 'all the rage', and insist that it is instead 'small and weak'. This comes just a few pages after they themselves boast of the field's 'new momentum, visibility, and sense of collective purpose', and after roping in giants from Ranke to E. P. Thompson as precursors. While the number of faculty positions defined as 'global history' may still be small, the prestige of the field, pace Drayton and Motadel, is currently very high.

But the main issue between us - and the one that Drayton and Motadel rather singularly fail to engage with - concerns what I called in my essay the 'small spaces'. My point was not that global history altogether neglects small spaces, and the events in them. Of course it does not. In my own field of early modern French history, I know and appreciate works such as Emma Rothschild's, cited by Drayton and Motadel, that show how even supposedly insular parts of the French kingdom like the city of Angoulême were profoundly affected by global patterns of exchange and imperial expansion. Nor would I argue with their point that 'all the fundamentalist upheavals and jihads of the last hundred years ... arose in response to increasing connection', or, for that matter, that nationalism 'responded to the new acceleration of European and global trade'.

My point was different, and quite simple. 'Small spaces' are not simply spaces that feel the impact of global forces. In some cases, they serve as profoundly intense, dynamic laboratories of change in their own right, and the processes of change that occur in them are much more than simple reactions to the global forces that impinge on them. Arabia in the age of Mohammed, Germany in the age of Luther, or Paris in the French Revolution are all spaces of this sort.

My criticism of some - not all - works of global history is that they do not take this enormously important aspect of the small spaces sufficiently into account. In discussing fundamentalist upheavals, jihads, and revolutions, such works imply that the only important thing to understand is the global background. But while this global background may be of crucial importance for understanding why these events began, it does much less to explain why they subsequently developed as they did. The collapse of the French monarchy in 1789, for instance, cannot be understood without reference to the contexts of global imperial competition, global trade, and global finance. But these global factors tell us much less about why the revolution subsequently radicalized, and eventually produced the reign of Terror. For that, we need to look in detail at the internal dynamics of the revolution, and also at cultural and intellectual factors that shaped the outlook of its actors - factors whose roots lie in large part in the longue durée of cultural and intellectual history. The same point also holds for the history of nationalism, about which Jeremy Adelman and I have both written extensively. Nationalism and nation formation have indeed both participated in and been reactions to global processes.

74 David A. Bell, 'Questioning the global turn: the case of the French Revolution', French Historical Studies, 37, 1, 2014, pp. 1-24. 
But if we look at them solely through this lens, we miss many of the other political, cultural, social, economic, and religious factors that have contributed to them. Of course there is nothing intrinsically 'Eurocentric' about the study of small spaces. Small spaces exist everywhere, and the sort of intense dynamics I am speaking of can be found in the history of many societies around the world. Fundamentalist upheavals and jihads are, in fact, perfect illustrations of my point.

Let me finish by saying that I am in no sense a blanket critic of global history. I have read, and appreciate, the classic works of the field cited by Drayton and Motadel, as well as their own impressive works. I have learned much from working in a history department known for its contributions to global history - contributions made, notably, by Jeremy Adelman. I myself am now working on a book that spans a larger portion of the globe than I have every previously engaged with, taking me from Europe to North America to the Caribbean. My argument was not with global history per se, but with some of the more exaggerated claims that have been made for it, and with some of the more ambitious attempts to equate it with the history of the world, full stop. If I used a little sharpness in the process, I plead guilty, but sometimes sharpness helps to provoke a useful debate. As indeed, in this case, it has done.

David A. Bell is the Sidney and Ruth Lapidus Professor in the Era of North Atlantic Revolutions at Princeton University. Among his recent books are Napoleon: a concise biography (2015); Shadows of revolution: reflections on France, past and present (2016); and

The West: a new history, co-written with Anthony Grafton (2 vols., 2017-18).

\section{Words from Jeremy Adelman}

A friend of mine told me a story a few months ago. He is on the editorial board of one of the discipline of history's most prominent journals. The board received a submission whose opening line gleefully announced that 'Now that global history is dead ...', with a footnote to my article of last spring in Aeon magazine. Drayton and Motadel have read it in the same spirit, as a 'lament', a 'rebuke', an argument against a field that should pack it in just because globalization is on the ropes, a plea for historians to spurn 'rootless cosmopolitan practitioners' and go back to the comforts of national history along with the Nation-X-firsters.

It is a shame that a pause for critical reflection on one's own field is taken as a rebuke, that in our bunkered times one has to be an unrepentant apologist or a mindless critic, that one cannot admit that changing presents warrant a fresh look or new turns on the past. That Drayton and Motadel keep confessing that David Bell and I put our 'fingers on many serious problems', only to wave them off in order to double-down against our concerns, makes me wonder what motivates them. The fact is, my essay ended precisely where theirs began - pointing out that the return of nativism has itself been a global phenomenon deserving of a global history. So, it is odd to be represented as a global history sceptic after decades in the field and in response to an effort to make the case for its continued importance in a new historic conjuncture.

While there is much to address in their essay, this reply focuses on three points. The first concerns the rhetorical portrait of the field of global history; the second points to a confusion 
about scales; and the third raises doubts about a habit of over-claiming the power of prized categories such as 'connection'.

First, Drayton and Motadel have a rhetorical knack for arguing that there is little new about the concerns we raise (as if, in any event, we laid claim to originality). One of the great values of their intervention is to catalogue centuries of historical analysis going back to its taproot in 'a history of all of humankind'. In some basic sense, of course, they are right. Historical inquiry does have a kind of evolutionary tree. But does this make it all 'global history'? If it does, then they are no doubt correct: the concerns that David Bell and I have raised are not new and the strategies for addressing them have been around for a long time. This of course solves one problem: there are not many thorny issues that global historians have not grappled with if the tent is so capacious as to include Herodotus, Sima Qian, Ranke, C. L. R. James, E. P. Thompson, Fernand Braudel, and so on. The solution creates another problem, however: global history includes just about everyone - and is therefore so overgrown as to be meaningless. Cast in this way, it is in danger of becoming a grab-bag of long-run, short-run, big-picture, small, wide, narrow, micro, macro, connected, disconnected, and now - if Drayton and Motadel have their way - including national histories. While I celebrate pluralism, I have issues with turning the field into a coalition of mush. I am not very interested in bounding and purifying. But some basic coherence helps it from slipping into Babelian nonsense.

They do, however, argue that global history 'as we know it' made room after 1950 for two new infusions: one from 'area studies' and the other from 'history from below'. Here, too, they are no doubt right. But the data confirm some reality checks. First, area studies never made as much of a dent on the trajectories of the discipline as we would often like to believe - and, to some extent, traditional area studies bear some of the responsibility for that. Second, the histories from below tended to get conjugated as a way to tell stories about the making of multicultural (or class) national communities, and so, while diasporas, migration, working-class, and women's histories helped pluralize and even transnationalize national framings, it is only much more recently that 'the below' really struck at the heart of the methodological nationalism and Eurocentrism that was the driving purpose of global history 'as we know it'.

Second, there is a fundamental confusion about the use of scale, and the insistence that we argue 'that global history implies a rejection of the smaller scales of historical experience, in particular the nation'. Really? That David Bell and I have both written extensively about nations and nationalism as part of, and reactions to, wider assemblages and processes might suggest otherwise. I myself have written quite extensively about one person as a genre of global history. Since David Bell has focused his reply largely on this question, I will not go into detail here - except to say that my own concern for restoring the importance of place in the wider matrix is precisely aimed at encouraging multi- and trans-scalar histories, ones that include the parts and places of the world that got disconnected and forgotten. I would add that this is no easy solution; it is no panacea. The jeu d'échelles is not a game for the exuberant novice unless one is going to persist in neglecting other languages, alternative archives, and different and discordant historiographies.

Third, there is an urge to over-claim the power of some concepts, an urge that is often legitimated by euphorias of a moment (as when globalization was the rage), and whose limits too often get papered over. The result is a propensity to use concepts that carry too much 
weight. When I was a graduate student, it was 'exploitation'. More recently, it has been 'connection'. When Sanjay Subrahmanyam began to make the term a coinage for an approach, he had a specific purpose: to explore the ways in which classical comparative and modernization history - why, for instance, state-building revolutions took some forms in Eurasia and other forms elsewhere - dissolved because the flows across the Eurasian ecumenes inhibited the clear separation of spaces. More recently, he has shown, in specific contexts and settings, how rulers and ruled produced commensurable meanings for courtly regimes. The key activity was 'translation', and Subrahmanyam goes into exacting detail about how that worked, including its limits and precariousness.

Lately, however, connectedness has become a sprawling word; border crossing became an exemplar and an explanation at the same time. And this has led to some muddled thinking. Seeing connectedness and entanglement has been very useful - strategic, in fact - in prying open methodological nationalism. But doing so has been summoned too often, for too long, to do too much. From the start, Drayton and Motadel tell us, ancient cultures were 'connected', which determined how each culture understood their particularity. But what does this mean? How does this work? Seeing the connection may be the easy part; it is just the start. But for too many global historians it is taken as the end in itself, as if it were self-evident how crossing boundaries worked to produce something different, as if - and here is where I most wanted to plant a red flag - connecting meant fusing and integrating. If anything, we might acknowledge that connection might lead to detachment, aversion, withdrawal, exit from entanglement. But to be able to cut through the knot of complex, interactive, and contradictory effects, we cannot rely so much on pointing to the motions, the line that fills in the dots, over space.

One cannot help but point out incongruities in Drayton and Motadel's portrait of global history. On one hand, it is an old vintage, reinvented in the 1950s, then again in the 1980s, then again after 2003 (always, it is worth pointing out, in this periodization, in Europe and the United States). And yet readers are told that it is 'young'. Readers are reminded how embracing it is - that pantheon of great names! - and yet are informed that 'few historians commit themselves to the comparative and connective approaches, the signature methods of global history as a genre'. A bit later on, we are told that 'it is small and weak', despite their claim that the discipline is on a roll. Which one is it? Then, some of the criticisms are simply wrong. Neither of us argued that global historians only study elite actors. The authors ask, rhetorically, 'is Adelman right that they [global historians] are only concerned about "integration and concord, rather than disintegration and discord"?' That is a good question. Adelman would be a moron if he did argue this. But this is not what he argued. What in fact he said was: 'The logic of global history tended to dwell on integration and concord, rather than disintegration and discord.' 'Only' and 'tended' are, actually, different words.

The incongruities represent an odd mélange of defensiveness and overreach. If there was a shared point that both David Bell and I were making in our cautionary notes, it has been the tendency to exaggerate the prowess of global history and what it might do for a discipline without making some critical adjustments and rethinking some basic assumptions and I, for one, have been among the chest-beaters, over-confident that global interdependence gave a structure to mutual understanding. The point of my Aeon article was, if anything, a call for a little more humility and a lot more clarity. If we are going to make good on any hope for a globally oriented history to inform a fragile, interdependent world, it will help to be more 
modest, to admit limits and disruptions, to be more uncomfortable, and to consider the sources of human detachments, ambivalences, and resistances to integration.

Jeremy Adelman is the Henry Charles Lea Professor of History and Director of the Global History Lab at Princeton University. His recent books include Worldly philosopher: the odyssey of Albert O. Hirschman (2013) and Worlds together, worlds apart: a history of humankind from beginnings to the present (5th edn, 2017).

\section{Drayton and Motadel: a response to Adelman and Bell}

The principal criticism in the replies from Bell and Adelman is that our essay falsely joins them in a straw man, and that we have misunderstood their 2013 and 2017 interventions. Readers of these texts may form their own view on this. It is reassuring to know that Bell no longer fears that the " "global turn", for all of its insights and instruction, has hit a point of diminishing returns'. It is good to understand that Adelman is now untroubled that 'resurgent ethno-nationalism' brings into question 'the point of recovering global pasts', and that he recognizes that global history already 'admits limits and disruptions'. Two elements of their replies, however, suggest that differences in our positions are sufficiently important (and revelatory) to require a short response.

Bell, first, pleads for 'small spaces' in which processes of change occur which 'are much more than simple reactions to the global forces that impinge on them'. This seems a version of the 'Russian doll' category error, gently mocked by Christophe Charle, which presumes that the global, national, and local must compete for our historical attention and nest neatly one inside the other. Our point - we think a deeper one, with wider implications for the methods of our discipline - is that interrogation of the specificity of the local and national is contingent upon open or tacit ideas about the universal and global. Global history, in other words, needs to be thought about when turning to the 'small spaces', which, in any event, themselves contain smaller spaces ad infinitum, as per Borges' jest in his short story 'On exactitude in science'. The macro and the micro are perspectives that need to be consciously brought into dialogue.

Adelman, second, is confused that we seem to suggest that global history is at the same time very old and 'young'. Our point was that global history is indeed both. As a genre, its precedents are ancient, because myths of distant strangers have always been the companion of the song of the tribe, which, as Marshall Hodgson noted, was the common melody at the origins of history. But our idiom of global history is a distinct, and fragile, outcome of social and intellectual change in the late twentieth and early twenty-first century. If it is thriving, 'on a roll' per Adelman, this does not mean that it is not still small and weak within our discipline, which remains thoroughly dominated by national history. The emancipatory and human promise of global history is very much a horizon of opportunity specific to our own age, if we dare. 